\title{
Influence of Natural Factors on the Position of Settlements and their Morphological Characteristics in the Example of the Municipality of Irig
}

\section{Miljković, Ljupče, Davidović, Rade Pavlović, Mila}

\begin{abstract}
Settlements on the territory of the municipality of Irig were mostly formed under the influence of physical geographic elements. Except physical geographic elements, other elements, socio-geographic for example, which are used for the settlement formation are of secondary importance and they are not excluded. Springs with a lot of water along each brook valley were very important for their formation. Every settlement in the municipality either very small, the type of Prnjavor (Velika Remeta) or the larger one such as the seat of the municipality (Irig) is connected to the springs of an area of Fruška gora. This was of crucial importance for choosing a place for the original construction of the settlements on the territory of the municipality of Irig. The settlements of the municipality of Irig are: Irig, Vrdnik, Mala Remeta, Jazak, Rivica, Velika Remeta, Grgeteg, Krušedol - Prnjavor, Krušedol - Selo, Neredin, Šatrinci and Dobrodol. The position of settlements and their morphology considerably depend on natural conditions, and in the example of the municipality of Irig, they especially depend on the relief and hydro-geographic conditions.
\end{abstract}

Key words: Irig municipality, Natural factors, Settlements, Vojvodina and Serbia

\footnotetext{
1 Ljupče Miljković, Rade Davidović Faculty of Natural Science, Department for Geography, Tourism and Hotel Management, Trg Dositeja Obradovića 3, 21000 Novi Sad, Serbia

2 Mila Pavlović

University of Belgrade, Faculty of Geography, Studentski trg 3/3, 11000 Belgrade, Serbia
}

\section{Introduction}

The municipality of Irig is situated in the central part of Srem (Vojvodina). The territory of the municipality covers two relief units: loess plateau of Fruška gora and south slope of Fruška gora. In relation to other municipalities of Vojvodina, the territory of the municipality of Irig is characterized, for the conditions of Vojvodina, by large vertical indentation of relief. The southern part of the municipality in the Borkovački potok valley (the district of Rivica) is situated on $110 \mathrm{~m}$ (a.s.l.) altitude. The altitude of $104 \mathrm{~m}$ (a.s.l.) is in the lower part of the district of Jazak. The northern border of the municipal territory is at the very crest of Fruška gora In the area of Iriški venac the northern border is on $444 \mathrm{~m}$ (a.s.l.) altitude, while in the region of Isin čot it goes to $522 \mathrm{~m}$ (a.s.l.) altitude. The vertical difference in altitude is $418 \mathrm{~m}$ relative height, on the compact territory of the municipality of Irig.

The mutual position of settlements on the territory of the municipality is very suitable. The settlement of Irig, an administrative center of the municipality, is situated in the central part of the territory. There are four set-

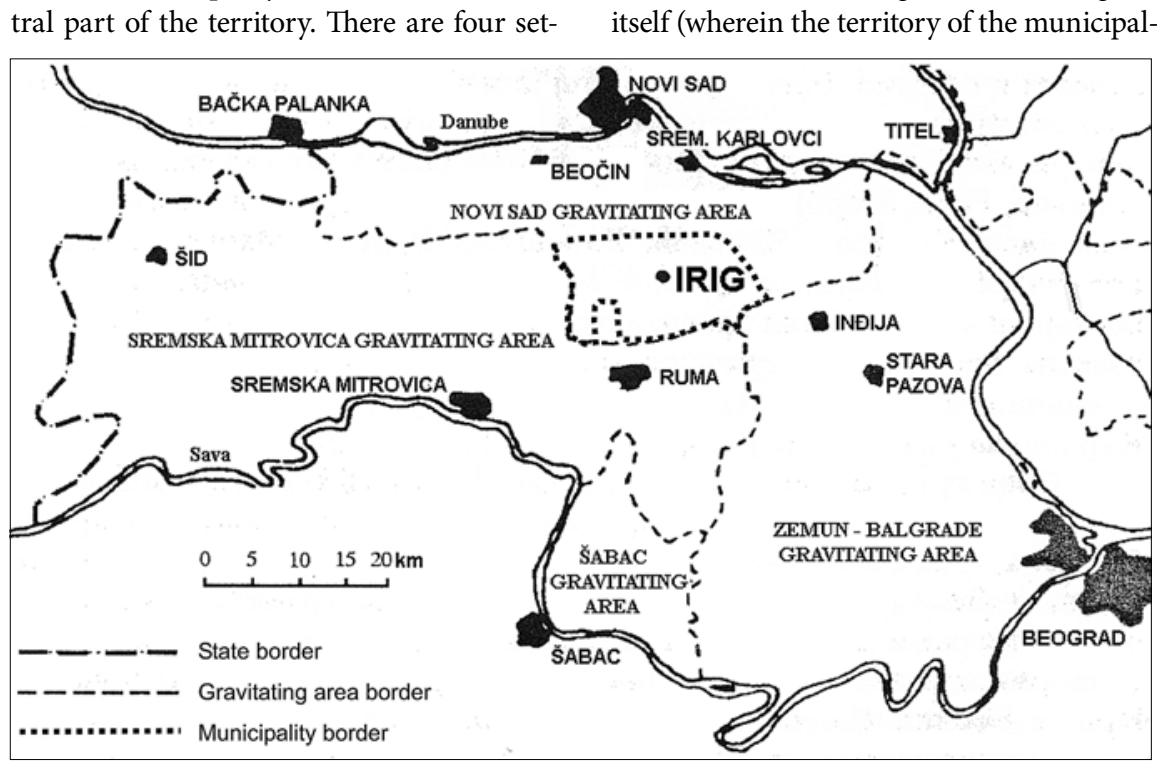

Figure 1 Geographical position of the Irig municipality in the Srem region Remeta, Jazak and Rivica, while there are seven settlements in the eastern part of the territory: Velika Remeta, Grgeteg, Krušedol Selo, Neredin, Šatrinci and Dobrodol.

The position of settlements and their morphology considerably depend on natural physical-geographic conditions and in the example of the municipality of Irig, they especially depend on the relief and hydro-geographic ones. The social conditions for forming the settlements are equally important as natural, but they are changeable more easily than the natural conditions. The social conditions are not the subject of this paper. If both kinds of the conditions were larger and more suitable during the formation of the village and its position, then the settlement grew faster, became stronger and developed.

\section{General characteristics of the settlements of Irig}

According to physical-geographic characteristics the area of Fruška gora and Fruška gora itself (wherein the territory of the municipal- tlements in the western part: Vrdnik, Mala 
ity of Irig mostly spreads) is suitable region for settlement. That is why this territory had been settled a long time ago. Abundance of antigorit nearby Jazak and Vrdnik had enabled their oldest inhabitants to make weapons and tools for themselves and for the inhabitants of much wider surrounding. Many things made of antigorit of Fruška gora were also found in neighboring Slavonija and parts of Vojvodina (Bukurov, 1954).

The position and arrangement of settlements of the municipality of Irig are caused by the same factors as the position of other settlements of Fruška gora. According to writings of an academican B. Bukurov "The position of settlements of Fruška gora is caused by several factors. The most important are: relief, hydrography, climate, economy, traffic, etc". The same author states further "... relief and hydrography were of crucial importance on getting the closer location of the settlement". The settlements of the municipality of Irig have especially been distinguished by these two crucial factors, relief and hydrography, which will be presented for every settlement separately in the section that follows. All the settlements of Fruška gora B. Bukurov divided into three groupings in his studies. The largest number of the settlements of Irig is classified into mountain settlements. They are located in such a way that inhabitants can use as much economic land as possible. Today, according to shape and extention of these settlemetns, it has not been so noticable as it used to be important in the past. The same author B. Bukurov states: "However it was not like that in the time of forming of these settlements, because in most of the cases they are built either at the end of the forest regions or in the very forests. The original task of almost all inhabitants was to clear the forests and bring new cultivated land to farming" (Bukurov, 1954).

Mountain and submountain settlements from the territory of the municipality of Irig are: Jazak, Vrdnik, Rivica, Irig, Neradin, Krušedol - Selo, Krušedol - Prnjavor, Velika Remeta, Grgeteg and Mala Remeta. Some of these settlements also belong to a type of Prnjavor settlements. These are: Mala Remeta, Velika Remeta, Grgeteg, Krušedol - Prnjavor, Jazački Prnjavor (today an integral part of the settlement of Jazak) and Vrdnički Prnjavor (today an integral part of the settlement of Vrdnik).

Ćurčić (1970) and Davidović (1989) wrote more about the origin of the settlements of Prnjavor, their characteristics and numerous problems. Thus, thirteen settlements belong to a group of the settlements of Prnjavor for the whole area of Fruška gora. However, all of them do not represent separate register circles, but they are considered as an integral part of the larger settlements like Jazački and Vrdnički Prnjavor that have already been mentioned.
Out of thirteen settlements of Prnjavor about a half (six) belongs to the municipality of Irig: Mala Remeta, Velika Remeta, Grgeteg, Krušedol - Prnjavor, Jazački Prnjavor and Vrdnički Prnjavor, wherefrom the first four settlements have the status of inhabited place (Davidović, 1989).

As topographic position concerned, Bukurov $(1954,1970)$ divided all the settlements of Vojvodina, the settlements of Irig also, on edge and internal. In his universal and detailed study Settlements of Srem, Curčić (2000) classified two settlements (Rivica and Irig) out of twelve of this municipality as edge settlements. They are located on the contact of mountain and loess plateau. All other settlements of the municipality of Irig the same author (Ćurčić, 200o) classifies into internal settlements. With this classification there is a difference among settlements built on Fruška gora (mountain), on loess plateau and on diluvium terrace. According to the same author, the first ones built on the mountain are: Jazak, Vrdnik, Neradin, Krušedol - Selo, Krušedol - Prnjavor, Velika Remeta, Grgeteg and Mala Remeta. All these villages have their locations at utmost south hillsides of Fruška gora. They are mostly located in the brook valleys, on the valley plane or at its mild sides. An exception is the village of Krušedol - Selo which was built right above hte Šelovrenac valley, in the higher part of loess plateau, that is, more exactly, on the contact of loess plateau and the hillsides of Fruška gora. Dobrodol and Šatrinci are internal settlements, but they are located on loess plateau. These two villages are located on plateau, but along the brook valley.

\section{Geographical position and morphological characteristics of the settlements of the municipality of Irig}

Irig is the largest settlement of the municipality and one of the largest settlements on the south slopes of Fruška gora. It lies on very important traffic artery that leaves Novi Sad and across Iriški venac and south hillsides of Fruška gora it comes down to Ruma. A local road that connects a number of villages on the slope of Fruška gora is being branched off this road. Therefore Irig has very suitable geographic position, but as railroad communications concerned it cannot be said so. The railroad traffic arteries bypass Irig, so in the view of transportation Irig is the primary road network. Nevertheless, it must be mentioned that a very important railroad track on Belgrade - Zagreb line goes south from Irig, which is of great importance for the whole development of the municipality. It is $11 \mathrm{~km}$ away from Irig, and the inhabitants and economy use it for passenger and goods transportation over railroad station of Ruma.
Concerning the geographic position of Irig the following was stated in the literature: "On determining the position of Irig two or three brooklets have been important, the villages of which meet into a wider one. These brooklets gave enough quantity of water, so the settlement could be developed freely" (Bukurov, 1954).

The district of Irig has a shape of an irregular rectangle set in the north - northwest south - southeast direction. It occupies the area of $55.1 \mathrm{~km}^{2}$ or $24.4 \%$ of the municipal territory, by which it is on the first position among twelve settlements on this area. The town itself has a suitable position comparing with the territory of the district because it is located in the central part of the district.

The territory which belongs to Irig lies on two geomorphological wholes. The higher relief article is a part of the mountain crest of Fruška gora and the lower part of loess plateau. These wholes were dissected by numerous brooks which had the primary role in forming the contemporary morpho - structural relief elements of this territory. The Jelence potok valley has the central importance for the town of Irig.

Today's morphology of this settlement is to a great extent a reflection of its past. The oldest part of Irig is immediately next to the brook. There are two parallel streets in this part, oriented the same as the brook, and separated by its bed. The rest part of Irig is on the higher land or on the watershed between one and the other brook valley. The main street of the whole settlement is oriented in the same way as Venac - Ruma main road is, by north - south direction. All other streets were formed according to this one. The pannonian influences can be felt in the construction of Irig because in most of the cases the streets are crossed at right angles. However, the influences of the mountain can also be felt, which are characterized with large compactness of the streets and houses, especially in the central part of the town (Bukurov, 1954).

In the past some streets of Irig had got special names which have been used even today. The streets are seldom called by their real, official names. Old street names are: Grčka mala, Mrtvi sokak, Madjarski kriz, Drum, Pijaca, Bela zemlja, Zlatna greda, Revido, Orašje, Srpski kertiz, Tabane, Sudski sokak and Vašarište. The streets mostly have the traffic function, especially Drum and Pijaca through which the road Novi Sad - Irig - Ruma goes. The center of Irig is situated in the middle part of the main street and it is called Pijaca.

Vrdnik is situated on the place where the spring branches of Veliki potok meet each other. It is located on the south slopes of Fruška gora. Its position is determined by the contact of the forest and the loess plateau of Fruška gora. It extends on $181-260$ $\mathrm{m}$ altitude, and it is located in the western 
half of the municipality of Irig. It lies in the central part of Srem, but it differs from other settlements of Srem. Its micro position is especially interesting. The settlements developed on the sides of the Dubočaša, Morintov and Veliki potok brook valleys. This settlement has steep streets and houses on the watersheds. The settlement of Vrdnik is situated in the central part of its district. As transportation concerned it is well connected with Irig over Rivica in the east and by the road Novi Sad - Irig - Ruma, with Belgrade - Zagreb highway, and with Bršenov and Crveni čot over Jazak and Mala Remeta in the west. It is connected with the northern piedmont of Fruška gora over Crveni čot. From the very settlement, directly towards the north, Vrdnik is connected with Partizanski put by asphalt road. Concerning its position Vrdnik is also characterized by suitable exposition. The settlement has sunny, south side exposition.

The total area of the district of Vrdnik is $33.7 \mathrm{~km}^{2}$. The district extends in the north - south direction in the length of 10 $\mathrm{km}$, with average width of $3.5 \mathrm{~km}$. According to its area it is one of larger districts of the municipality of Irig.

Concerning its relief the settlement of Vrdnik is situated in the central part of the southern slopes of Fruška gora. Geomorphologically the district extends over two relief wholes, north mountainous and south, plain. The hillsides of Fruška gora represent the mountain part. The highest peaks of Fruška gora are at the rear of this district: Crveni čot $538 \mathrm{~m}$ (a.s.l.) and northeastern Kraljevska stolica peak 484 $\mathrm{m}$ (a.s.l.). The settlement is in the basin of Vrdnik, which represents the tectonic erosion extension, and the loess plateau of Fruška gora is on the south of it. The basin has an amphitheatric shape divided by the brook valleys. Thus the relief of this area has a rolling shape.

In the morphological view it can be said for Vrdnik that this is mixed settlement, as by its physiognomy so by its function. Zones of summer cottages of people from Novi Sad and Belgrade are in the vicinity of Vrdnik, in Venj, Kula and Majdan. Vrdnik is the settlement of around forty streets. About ten of the longest ones have been asphalted.

Jazak is located in the western part of the municipality of Irig. The village is situated on the south slopes of Fruška gora. It is located in the Rovča potok valley. The settlement has a suitable position because it is located in the part where the hillsides of Fruška gora get into the loess plateau of Fruška gora. The altitude of the village ranges from 140 to $260 \mathrm{~m}$ (a.s.l.). The difference between the highest and the lowest point of the district is $432 \mathrm{~m}$ (a.s.l.), which is reflected on the climatic, hydro - geographic, relief, pedological as well as antro- pographic differences between the northern and southern parts of the district. The settlement was built in the central part of the district of Jazak. The district of Jazak extends in the north - south direction and it is much lengthened. The length of the district is 2.5 to $3.0 \mathrm{~km}$. The total area of the district is $34.98 \mathrm{~km}^{2}$.

The district of Jazak extends over two basic relief wholes: mountain area and the loess plateau of Fruška gora. The mountain part spreads to the highest parts of Fruška gora. Both relief wholes are dissected from the Rovača potok and its tributaries.

The settlement of Jazak is oval. It is located in the Rovača potok valley. This village grew together with the neighboring Prnjavor. Three parts can be distinguished in this settlement: Jazak - Selo (the narrower part of the village) Bikoč, and Jazak - Prnjavor. Except the villages on the northern part in the zones of the district of Zabalje and Carina there is a weekend settlement also where people who spend weekends there are mostly from Novi Sad, less from Sremska Mitrovica and Belgrade.

Neradin is situated on the south slopes of Fruška gora. It is located in the Neradinski potok valley, the spring branch of the Kalinjak brook. Asphalted road connects the settlement with Irig on the west, and on the east with Krušedol - Prnjavor. The village is posited on $184 \mathrm{~m}$ altitude (a.s.l.). The area of the district of Nerodin is $13.77 \mathrm{~km}^{2}$.

In the view of relief, the zones of the northern part of the district of Nerodin belong to the mountain area of Fruška gora. There are large slopes there and the relief is dissected by the spring-head sapping of the Kalinjak brook. The lower parts of this district are on the loess plateau of Fruška gora. The loess plateau has also been dissected by the brooks and their valleys of the Kalinjak, Kajinovac and Luka potok.

This settlement belongs to a group of brook settlements, and it could be classified into mountain settlements of the area of Fruška gora. The settlement is compact. The street network and he houses follow the configuration of the terrain, so the streets are winding. The central part of the village is called Orašje while the western part is called Veliki šor. Except that the village is compact it has an extended shape along the brook and road that proceeds to Krušedol - Irig road.

Rivica is located in the western part of the municipality of Irig. It mostly gravitates to the municipal centre of Irig, from which it is only $3 \mathrm{~km}$ away. The area of the district of Rivica is $20.32 \mathrm{~km}^{2}$. It extends in the central part of the south piedmont of Fruška gora. The direction of this district's extension is north - south in the length of $10 \mathrm{~km}$ with an average width of $2.5 \mathrm{~km}$. The northern part of the district reaches the height of $475 \mathrm{~m}$ altitude while the southern part is lower, only $120 \mathrm{~m}$ altitude. The settlement itself is on $170 \mathrm{~m}$ altitude.

Taking the morphometric characteristics and geological structure into account, three relief wholes can be distinguished: mountain area, loess plateau and brook valley (Borkovački potok).

Rivica was built on loess plateau between the dale, of the Berkovac brook and one small side dale. These micro relief shapes determined the triangular base of the village in morphology. The plateau on the south side of the valley represented particularly a suitable location for settling. The settlement is extended in the southeast - northwest direction. The settlement is around $1.5 \mathrm{~km}$ long and it spreads on both sides of Irig - Vrdnik road. There are three parts of the village. A part of the settlement called Gornji kraj is corresponding to the direction of extending of the main street. A part called Vorsovo corresponds to the direction of extending of Palih boraca Street, and the third part which is called Klisa corresponds to Vojvodjanskih brigada Street.

Krušedol - Selo is situated in the valley of the Šelovrenac brook, on the southern slopes of Fruška gora on 160 to $180 \mathrm{~m}$ altitude. The district of this village has an area of only $8.96 \mathrm{~km}^{2}$. Morphologically, the district extends across two relief wholes. Its northern part extends on the southern slopes of Fruška gora and it is included into mountain part, while the southern part is much narrower and it is located on the loess plateau of Fruška gora. Both relief wholes were dissected by spring branches of the Šelovrenac brook.

Krušedol - Selo is a small mountain settlement of the municipality of Irig. In morphology and type it is also a brook settlement because it was built in the widened valley of the Šelovrenac brook. It is a compact settlement. The streets are winding and they follow the relief wholes. Karlovačka Street is a little more regular. Almost all streets have the same north - south direction of extending as the Šelovrenac brook.

Šatrinci is located in the southeastern part of the municipality of Irig. The village is situated on the loess plateau of Fruška gora on $126 \mathrm{~m}$ (a.s.l.) altitude. It is situated in the valley and valley sides of Kalinak brook. The settlement is in the central part of the district. The area of the district is $5.75 \mathrm{~km}^{2}$. Šatrinci is a pannonian type of the settlement, a typical village of Vojvodina with straight streets laid out.

Krušedol - Prnjavor lies on the loess plateau near the village of Krušedol, in the flow area of the Šelovrenac brook (the village is situated from the right side of Manastirski potok, the component of Šelovrenac). The village is $180-210 \mathrm{~m}$ (a.s.l.) altitude. The district of Krušedol - Prnjavor has south east - northwest direction, with length of about $12 \mathrm{~km}$, and width is $2.5 \mathrm{~km}$ average. 
The area of the district is $24.8 \mathrm{~km}^{2}$, and it is one of larger districts of the municipality of Irig. The district mostly extends on the loess plateau of Fruška gora. Within the relief of the district are the brook valleys of the Šelovrenac and Monastery brooks.

The village has triangular base. In recent times the village extends along the road for Irig by family houses construction (with a help of International Community) for refugees and exiles from Croatia and Bosnia and Herzegovina. In this way the village loses its original triangular shape because the houses are built as along the road for Irig so along the road for Grgeteg and Krušedol - Selo.

Mala Remeta is situated on the utmost western part of the municipality of Irig, on the loess plateau which was cut by Mali potok. This brook is one of the tributaries of Stojanovački gat. The village is on $250-$ $260 \mathrm{~m}$ (a.s.l.) altitude. It belongs to a group of higher settlements of the area of Fruška gora and the municipality of Irig. By its position this village differs from other settlements of Prnjavor. The monastery near which this village was built is in the Mali potok valley, and the village itself is a little higher, on loess plateau. The village extends in the north - south direction. The same direction the district of Mala Remeta also has. The district is $8 \mathrm{~km}$ long, while the average width is hardly about $1000 \mathrm{~m}$, so the area is only $8.87 \mathrm{~km}^{2}$.

The district extends in the area of two relief elements: Fruška gora, mountain part, and loess plateau of Fruška gora. Mala Remeta is the settlement of Prnjavor. Its formation was connected to the neighboring monastery having the same name. It is also a road settlement. There is only one street in it along which houses were built.

Dobrodol is a village southeast from Irig. The district of the village occupies the utmost southeastern part of the municipality of Irig. The altitude ranges from 110 $\mathrm{m}$ (near the very brook of Medjaš which intersect this district) to $138 \mathrm{~m}$ in the northern part of the district, that is, in the area of Čaut. Dobrodol was built along right valley sides of Dobrodolski potok.

As relief concerned, the district extends on loess plateau. An observer is given an impression of an ideal plain. This plain was dissected by the valleys of two brooks: Medjaši and Dobrodol.

Considering that the basic economy branch is agriculture, the village looks like that. Dobrodol is typical agricultural settlement, compact one with straight streets laid out. All houses are family and ground floor. The village does not have a typical center, but it consists of three streets. The main street has the north - south direction, and it is intersected by two transversal streets.

Grgeteg is situated in the north - eastern part of the municipality of Irig. By its position it belongs to higher settlements of the municipality of Irig. It is located in the Kalin potok valley. The village was built in the place where the valley of the Kalin brook extended, south from the monastery of Grgeteg. The settlement has an average altitude of $260 \mathrm{~m}$ (a.s.l.). Comparing with the district this settlement occupies approximately the central position. The district extends in the southeast - northwest direction in the length of $6.5 \mathrm{~km}$, and width of 600 to 1500 meters.

As far as relief concerned larger part of the district is mountainous. The area of $310-340$ meters altitude was cut into older terrain of the anticline of Fruška gora. It comes to a sudden bend in the relief below the monastery itself. Loess, slopes with pebble layers, mixture of lake and aeolian sediments appear on the sides of the brook valleys.

Today's appearance and morphology of the village are such that it consists of two rows of houses laid out irregularly on both sides of Kalina potok.

Velika Remeta is situated on the south ern slopes of Fruška gora. The settlement is located in the spring crest of the Šelovrenac brook, in the extended part of the Monastery brook (the upper part of the Šelovrenac brook), and just on the place where three spring branches meet themselves and make the spring crest of Šelovrenac. On that place the centre of the village is on $240 \mathrm{~m}$ altitude. Summer cottages which also represent an integral part of the settlement are located northeast from the center.

The district of the village is pear shaped, where the northern, wider part reaches the very crest of Fruška gora. The district spreads on the relief wholes: mountain sides, the brook valley sides, while the narrower south part is in area of loess plateau.

The village of Velika Remeta belongs to a type of mountain settlements. By the typology and shape this settlement is extended. It is a settlement of Prnjavor. There are around sixty houses for the permanent and periodical residence. A number of summer cottages were built on the slopes of Manastirski potok, which gives an impression of dispersed type of the settlement.

\section{Conclusion}

The settlements on the territory of the municipality of Irig were mostly formed under the influence of relief and hydrographic conditions (the most important physical geographic elements of an area). Except physical geographic elements, other elements, socio - geographic for example, which are used for the settlement formation, are of secondary importance and they are not excluded. The springs of a lot of water along each brook valley were very important for the settlement foundation on those plac- es. Every settlement of the municipality either very small, the type of Prnjavor (Velika Remeta with a couple of around ten permanent inhabitants, more exactly, according to the register of 200242 inhabitants) or larger like the seat of the municipality of Irig is (Irig with several thousands, according to the register of 20024848 inhabitants) is connected with the springs of the area of Fruška gora. This was of crucial importance for choosing the places for original settlement construction.

The types of the settlement and its morphology are in close connection to its position, economic - traffic, socio - economic conditions and military - strategic functions (especially in the past). All these factors influenced on the formation of the settlements of compact type. The relief caused that almost all settlements of the municipality of Irig, except Šatrinac and Dobrodol, belong to a type of mountain and sub-mountain settlements. The streets are compact, narrow and bend towards the brook valleys. Finally, it is necessary to mention the monasteries, too around which the settlement with a type of Prnjavor developed. It is also useful to mention the weekend settlements that were built around Irig, Vrdnik, Krušedol and other places in recent years (in the district of Velika Remeta there are more summer cottages than permanently inhabited houses in the village itself for example).

\section{References}

Bukurov, B. 1954. Geografski položaj, tipovi i oblici fruškogorskih naselja. Zbornik Matice srpske za prirodne nauke 7, 1-48 .

Bukurov, B. 1970. Gravitacione sfere vojvodjanskih gradova. Spomeniica u čast novizabranih članova SANU, vol. 44, 119-138.

Davidović, R. 1989. Prnjavorska naselja u opštini Irig. Zbornik radova Instituta za geografiju 19, 111-122.

Davidović, R., Pavlović, M. 1998. Banje fruškogorske oblasti kao faktori razvoja turističke privrede. Zbornik radova Instituta za geografiju 30, 109-115.

Davidović, R., Miljković, Lj. 1995. Opština Irig - geografska monografija. PMF, Institut za geografiju, Novi Sad, pp. 1-223.

Davidović, R., Pavlović, M. .2005. Prostorni razmeštaj i položaj naselja u opštini Alibunar. Srbija i savremeni procesi u svetu, Geografski fakultet, Beograd, PMF, Novi Sad, Odsek za geografiju PMF-a, Priština (Kosovska Mitrovica), Odsek za geografiju, PMF, Niša, pp. 623-628.

Ćurčić, S. 1970. Prnjavorska naselja u Fruškoj Gori. Zbornik Matice srpske za prirodne nauke 38, 201-213.

Ćurčić, S. 200o. Naselja Srema - geografske karakteristike. Posebno izdanje, PMF, Institut za geografiju, Novi Sad, pp. 1-249. 